\title{
Effects of hydraulic shellfish dredging on the ecology of a cultivated clam bed
}

\author{
Ronald Goldberg*, Renée Mercaldo-Allen, Julie M. Rose, Paul Clark, \\ Catherine Kuropat, Shannon Meseck, Jose Pereira
}

NOAA Fisheries, Northeast Fisheries Science Center, Milford Laboratory, 212 Rogers Avenue, Milford, Connecticut 06460, USA

\begin{abstract}
A before-after-control-impact (BACI)-style experimental design was used to assess the short-term effects of hydraulic clam dredging on the benthic community of a leased shellfish bed along the Connecticut coast of Long Island Sound, where hard clams Mercenaria mercenaria are cultivated. Three replicate samples were collected from 6 plots ( 0.67 ha each) on a weekly basis from May through October 2009. Dredging was conducted in early July in 3 of the 6 plots, while 3 control plots were not dredged. Pairwise comparisons and multivariate analyses of main effects and interactions indicated that ecological indices did not differ significantly between dredged and not dredged plots, although sample date and plot both had significant effects. Assemblages of individual species were associated with specific sediment types found within the clam bed. Natural seasonal settlement patterns and sediment grain size had a greater influence on the benthic community than discrete hydraulic clam dredging.
\end{abstract}

KEY WORDS: Benthic macrofauna - Species composition · Before-after-control-impact design · Mercenaria mercenaria · Molluscan aquaculture

\section{INTRODUCTION}

Globally, the use of towed fishing gear has been of concern, because of the potential for mortality to non-target organisms and habitat disruption (Levy 1998, Watling \& Norse 1998, Baulch 1999, Watling 2005). These important issues must be balanced with the world's need to produce high-quality food and the associated economic benefits of marine aquaculture. Carefully managed aquaculture of molluscan shellfish has the potential to increase production of seafood with minimal and acceptable impacts to the environment (Shumway 2011). Cultivation of filterfeeding shellfish that remove nutrients from seawater can provide environmental benefits to eutrophic coastal areas (Newell 2004, Lindahl et al. 2005, Ferreira et al. 2007). Use of leased beds in aquaculture, where the leaseholder has resource rights, allows for mollusk cultivation that is more similar to terrestrial farming than to commercial fishing for a shared resource on common grounds.

In Long Island Sound, the hard clam industry relies on natural recruitment in the cultivation process. Harvest of hard clams from Connecticut waters has increased steadily since the 1990s (Long Island Sound Study 2011). Currently, over 28328 ha of leased shellfish grounds are under cultivation in coastal Connecticut; recent shellfish harvests have exceeded $15857 \mathrm{~m}^{3}$ of hard clams Mercenaria mercenaria and $7047 \mathrm{~m}^{3}$ of oysters Crassostrea virginica, providing over 300 jobs and $\$ 30$ million in revenue annually (Connecticut Department of Agriculture 2011). Shellfish beds, leased by the state to individual growers, are dredged to harvest marketable clams and are then left fallow for 3 to $5 \mathrm{yr}$, allowing natural seed clams to grow to commercial size. Depending on the size of the bed and standing stock, clam dredging may be completed within a period of hours or con- 
tinue over several days. This type of cultivation, as practiced in Connecticut, can be described as extensive in contrast to intensive cultivation, where hatchery-reared seed clams are grown within cages or under protective netting.

Hard clams, burrowed within sediments, are typically harvested with towed hydraulic dredges, where a pump on the fishing vessel sends water through a hose to a manifold on the dredge. High pressure jets loosen sediment, and dislodged clams are collected in a chain mesh bag as the dredge bar passes through the fluidized sediment (MacKenzie et al. 2002). Water pressure must be sufficient to loosen sediments, but not so great as to damage clams (Jolley 1972). Performance of a hydraulic dredge varies with sediment type, exhibiting greater efficiency when used on sand compared to soft mud bottom (Jolley 1972). Typically, hydraulic clam dredges weigh between 200 and $400 \mathrm{~kg}$ and measure from 0.6 to $1.0 \mathrm{~m}$ in width. Design and operation of a dredge determine both harvesting efficiency and the degree of seafloor disturbance (Larry Williams, Jesse D. Shellfish Company, pers. comm. 2009).

Many studies have investigated disturbance and subsequent ecological recovery of the benthos associated with hydraulic dredging of molluscan shellfish (e.g. Sparsis et al. 1993, Gilkinson et al. 2005, Morello et al. 2005). Physical, chemical, and biological effects of dredging can vary widely and are dependent on the intensity, duration, and spatial scale of the impact (Mercaldo-Allen \& Goldberg 2011, Stokesbury et al. 2011). Additionally, habitat characteristics, sediment biogeochemistry, hydrodynamics, seasonal recruitment, and benthic community structure are among the many factors that influence rate of recovery from dredge harvesting. Regional variations in harvesting gear and methods, along with geographic ecological differences, make it difficult to generalize results from specific studies.

Designing experiments to assess the effects of hydraulic dredging on the marine benthos is challenging, since the goal is to measure change in a fluctuating environment. Before-after-control-impact (BACI) studies are often used to distinguish naturally occurring environmental variability from changes induced by manmade activities (Dame et al. 2000, 2002, Hewitt et al. 2001) and have been applied to study fishing effects on benthic communities (Mercaldo-Allen \& Goldberg 2011, Stokesbury et al. 2011). Preliminary 'before' sampling in BACI-style experiments provides a baseline for assessment of dredging effects and identification of environmental or biological factors that could confound analysis (Kaiser 2005).
We used a BACI-style design to examine the effects of hydraulic clam dredging on the benthic community within a shallow coastal study site in Long Island Sound, Connecticut, USA. In an experiment conducted on a leased clam bed, we sampled the benthos multiple times before and after an industry partner hydraulically dredged specific plots to harvest clams. Other plots from the same clam bed that were not dredged were sampled as control treatments to measure the effects of disturbance and to distinguish those effects from naturally occurring community variation attributed to seasonality and differences in sediment grain size.

\section{MATERIALS AND METHODS}

\section{Study site}

The 4 ha study site used for the experiment was located within an actively cultivated clam bed, west of Charles Island and offshore of Laurel Beach in Milford, Connecticut, at approximately $41^{\circ} 11^{\prime} \mathrm{N}, 73^{\circ} 5^{\prime} \mathrm{W}$ in Long Island Sound (Fig. 1). Seawater depths at the study site varied over the tidal cycle from $4.9 \mathrm{~m} \mathrm{(16 \textrm {ft } )}$ to $6.1 \mathrm{~m}(20 \mathrm{ft})$. Leased shellfish beds in this area have been fished intermittently over the past $20 \mathrm{yr}$. Hard clams were most recently harvested commercially from the site by hydraulic dredge in 2007 . The study site was subdivided into 6 plots ( 0.67 ha each): representing 3 'dredged' (Plots $1,3,5)$ plots and 3 'not dredged' controls (Plots 2, 4,6). Each plot was further divided into 9 boxes to allow for spatially randomized sampling.

\section{Experimental design and sampling}

A BACI-style experiment was used to evaluate the impact of shellfish harvest dredging on benthic assemblages. We compared 3 'dredged' (Plots 1, 3, 5) plots to 3 'not dredged' controls (Plots 2, 4, 6). Sampling was conducted prior to or 'before' the experimental dredging and 'after' experimental dredging on all 6 plots.

Beginning on May 28, 2009, field sampling was conducted at 1 or 2 wk intervals from aboard the NOAA Fisheries RV 'Victor Loosanoff'. Sediment was sampled from 3 randomly selected boxes within each of 6 plots using a Smith-McIntyre grab, providing a total of eighteen $0.1 \mathrm{~m}^{2}$ sediment samples. GPS coordinates were recorded for each individual grab. The sediment depth in each grab sample was measured 


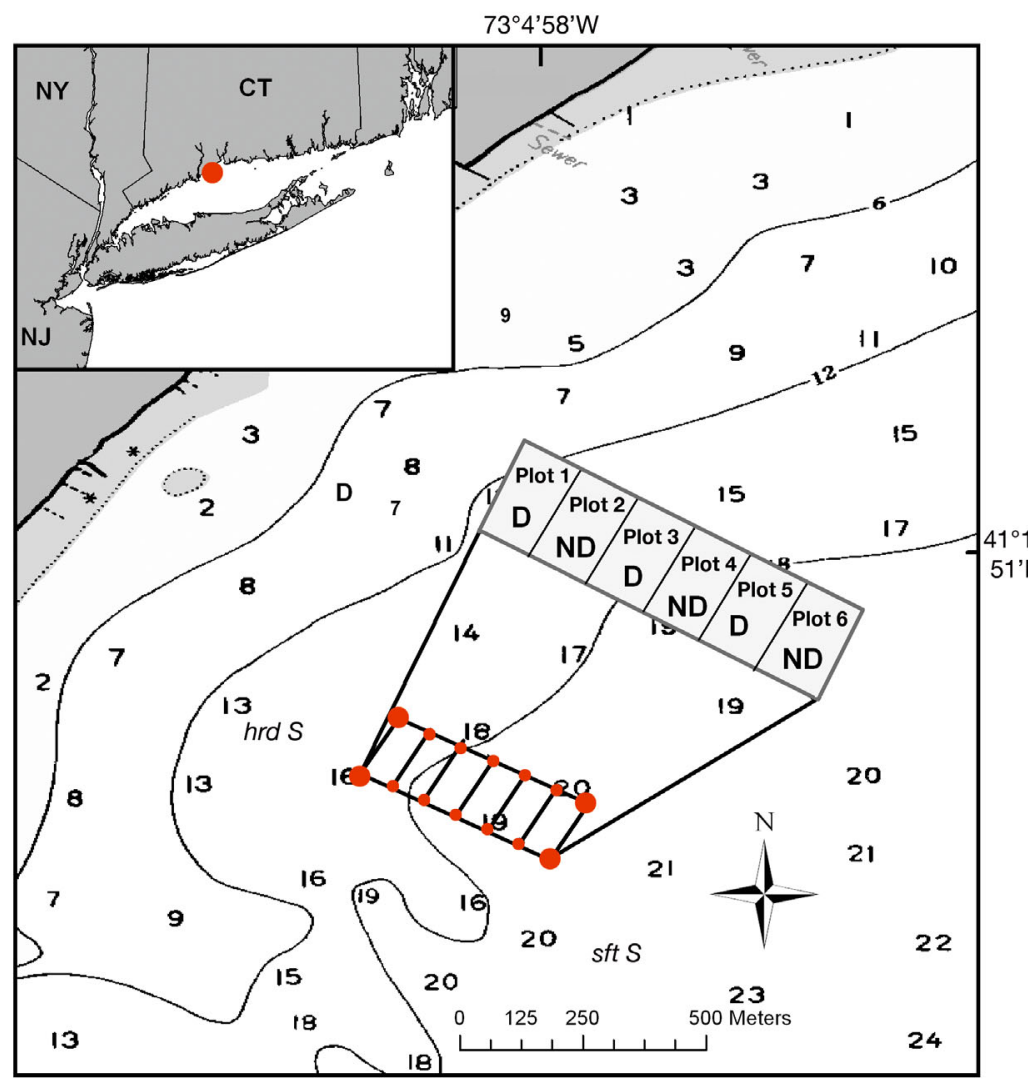

Fig. 1. Study site in Long Island Sound (inset) off the coast of Milford, Connecticut, USA. Projection shows a schematic of the 6 experimental plots $(82 \times 122 \mathrm{~m}$ each), indicating dredged (D) and not dredged (ND) plots. Depths at mean low water are indicated in feet $(1 \mathrm{ft}=0.31 \mathrm{~m})$. hrd (sft) S: hard (soft) sand

in millimeters, and a subsample of sediment was removed for grain size analysis. Sediment chemistry sampling was conducted concurrently on benthic sampling trips (S. Meseck unpubl. data). Environmental data, including temperature, salinity, and dissolved oxygen, were measured near the sediment water interface at the beginning and end of the trip using handheld Yellow Springs Instrument Co. optical dissolved oxygen, temperature and salinity meters.

Dredging was conducted once on July 6, 2009, by a commercial clam vessel, operated by the Jesse D. Shellfish Company. Plots 1, 3 and 5 were dredged at towing speeds of 1.2 to 1.6 knots. The duration of dredging was $1 \mathrm{~h}$ and covered the entire 0.67 ha area of each plot, which was sufficient to remove most of the marketable hard clams. The hydraulic clam dredge measured $61 \mathrm{~cm}$ in width, weighed $204 \mathrm{~kg}$, and produced a water pressure of $1.97 \mathrm{~kg} \mathrm{~cm}^{-2}$ passing through $30.5 \mathrm{~m}$ of a $10.2 \mathrm{~cm}$ diameter hose to a $1 \mathrm{~cm}$ diameter manifold pipe. The manifold was positioned $35.6 \mathrm{~cm}$ from the teeth which were set at a $12^{\circ}$ angle, resulting in sediment penetration to a depth of 25 to $76 \mathrm{~mm}$.

We continued 'after' sampling of 3 sediment grabs from randomized locations within each of the 6 plots until October 26, 2009. A total of 12 sampling trips were completed over a 24 wk period from May through October 2009. Sediment collected in the grab was transferred to a pan and washed through 4 and $1 \mathrm{~mm}$ mesh sieves. Live animals on the $4 \mathrm{~mm}$ screen and all the material retained on the $1 \mathrm{~mm}$ screen were transferred to storage jars for sorting at the laboratory. Samples were sorted using 10x lighted magnifiers, and all live organisms were removed and held in a refrigerator for 24 to $48 \mathrm{~h}$. Organisms were then counted and identified to the lowest taxon possible (Pollock 1943, Smith 1964, Gosner 1978, Weiss 1995).

During most weeks in which sediment collections were made, epibenthic juvenile finfish and invertebrates on the experimental plots were sampled using a $1 \mathrm{~m}$ beam trawl with a $3 \mathrm{~mm}$ mesh net. Three boxes were randomly selected from within each of the dredged and not dredged areas, and 2 trawls were conducted per box, for a total of 12 samples, 6 from each treatment. Tows, about 2 to 3 min in duration, were made over the longest dimension of each plot (approximate distance of $137 \mathrm{~m}$ ) at a speed of about 1 knot. Juvenile fish and invertebrates were identified by species and counted.

\section{Data analysis and statistics}

Prior to statistical analysis, abundance estimates from individual grab samples were averaged across each plot on each sample date. A BACI-style statistical analysis of main effects and interactions was performed using the permutational multivariate analysis of variance (PERMANOVA) add-on to the statistical software Primer v6 (Clarke \& Gorley 2006, Anderson et al. 2008). PERMANOVA was used to determine the main effects of treatment (dredged vs. not dredged), time period (pre-dredging vs. post-dredging), sample date (nested in time period), plot (nested in treatment), and interactions between time period $\times$ treatment, time period $\times$ plot, and sample date $\times$ treatment. This 
analysis was completed for the total benthic community, the annelid and mollusk community subsets, and several ecological indices. Square-root transformation was applied, and the Bray-Curtis resemblance measure was used to generate similarity matrices for the total community and community subsets. Complementary ecological indices were calculated using the DIVERSE routine in Primer, and included Margalef's index of species richness, Pielou's index of evenness, and the Shannon index of diversity. A fourth-root transformation was applied to the number of individuals' dataset to generate a more even distribution of points. Euclidean distance was used as the resemblance measure for all ecological indices.

Non-metric multidimensional scaling (NMDS) was combined with analysis of similarity (ANOSIM) tests to explore the influence of other temporal and environmental factors on benthic community composition (Clarke \& Warwick 2001) using Primer v6. The NMDS plot of sample relationships for all sample plots and sampling dates was overlaid with associated categorical variables, including sample month (as a proxy for seasonality) and sample plot number (to explore potential correspondence with observed grain size differences). ANOSIM tests were performed based on plot and month groupings to assess effects of grain size and season, respectively. ANOSIM was also used to compare abundance of juvenile fish between dredged and not dredged areas.

Canonical analysis of principal coordinates (CAP) was used to perform a discriminant analysis based on sediment grain size, i.e. to identify the axis through the multivariate data cloud that best separated the samples according to this factor (Anderson et al. 2008). Samples were grouped according to the results of the grain size comparison, i.e. Plots 1, 2, and 3 were grouped together, Plot 4 was kept separate, and Plots 5 and 6 were grouped together within the analysis. A Spearman rank correlation was then calculated for individual species to identify associations with the first CAP axis that best separated grain size groups. A repeated measures test was used to determine if differences between dredging treatments were masked by larger plot-related sediment grain size differences. A percentile bootstrap method for comparing trimmed means of 2 dependent groups based on difference scores was used. A percentile bootstrap method for multiple comparisons was also used to test for pairwise differences in sediment grain size between plots. Both tests are described in the publication by Wilcox (2003). The statistical software program R, Version 2.13, was used to perform these comparisons (www.r-project.org).

\section{RESULTS}

\section{Environmental sampling}

Seasonal seawater temperatures ranged from 13.9 to $23.6^{\circ} \mathrm{C}$ during the experiment. Mean salinity during the season was $25.52 \pm 0.34$. Dissolved oxygen levels remained above saturation, with a mean of $6.64 \pm 1.39 \mathrm{ppm}$.

Mean $( \pm \mathrm{SE})$ sediment depth of all grab samples was $5.3 \pm 0.14 \mathrm{~cm}$. A gradual transition in sediment grain size from fine sand to very fine sand was detected across the study area. Sediments in Plots 1 to 4 were all nominally classified as fine sand, with a mean $( \pm \mathrm{SE}) \Phi$ size of $2.50 \pm 0.03$. Sediment in Plots 5 and 6 had the smallest grain sizes and were nominally classified as very fine sand with a mean $( \pm \mathrm{SE}) \Phi$ size of $3.15 \pm 0.06$.

\section{Experimental harvest of hard clams}

Hard clams Mercenaria mercenaria harvested from the dredged plots at the beginning of the experiment, included 3 different size classifications. Approximately $0.78 \mathrm{~m}^{3}$ of littlenecks ( 25 to $50 \mathrm{~mm}$ width) and $0.63 \mathrm{~m}^{3}$ of topnecks (50 to $76 \mathrm{~mm}$ width) were harvested. Smaller 'seed' clams $(<50 \mathrm{~mm})$ also collected in the dredge were returned to the bed.

\section{Benthic sampling}

Sixty-eight species of benthic organisms (Table A1 in Appendix 1) were recovered and identified from all Smith-McIntyre grab samples. The numerically dominant species included amphipods, Ampelisca spp., and Unciola irrorata; polychaetes, Clymenella torquata, Glycera spp., Nephtys spp., Drilonereis spp., Amphitrite spp., and Pectinaria gouldii; and bivalves, Mercenaria mercenaria, Mya arenaria, Ensis directus, and Yoldia limatula. Dominant gastropod species were Turbonilla spp., Illyanassa trivittata, Urosalpinx cinerea, and Crepidula fornicata. Most of the mollusks sampled were small non-commercial species, primarily individuals $<10 \mathrm{~mm}$ in length. In late July we found 165 newly settled sea stars Asterias forbesi, but this species was not detected in subsequent samples.

\section{BACI analyses}

The BACI-style analyses of main effects and interactions indicated no significant differences between 
the dredged and not dredged treatments for the benthic community as a whole or any of the ecological measures, including number of species, number of individuals, and the Margalef richness, Pielou evenness, and Shannon diversity indices (Table 1). Similarly, no differences were detected for total molluscan or total annelid abundance (Table 1). No significant interactions between treatment and sampling date or treatment and pre-/post-dredging were observed. However, consistent significant differences were observed for nearly all ecological indices across sampling dates and plots. A significant interaction for pre-/post-dredging $\times$ plot was observed for the Margalef and Shannon diversity indices. Pairwise comparisons of Margalef richness pre- vs. postdredging for each plot showed significant differences for all 6 plots. Comparisons of Shannon diversity indicated significant differences in pre- vs. postdredging in Plots 4, 5, and 6. Graphs for the ecological parameters further illustrate high similarity between the dredged and not dredged plots over the sampling season (Fig. 2).
The BACI analysis indicated consistent differences related to plot and sampling date. We used NMDS, CAP, and ANOSIM to explore whether these differences were related to seasonality and sediment grain size. An NMDS plot of whole community data overlaid with sampling month, shown in Fig. 3, suggested structure in the data related to season, observations that were supported by ANOSIM tests based on month. Samples grouped by month yielded significant differences (global R statistic $=0.424, \mathrm{p}=0.01$ ) between communities for every pair of months compared, except May versus October $(p=0.139$; all other pairwise comparisons $\mathrm{p}<0.05$ ).

The comparison of sediment grain sizes across plots yielded no significant differences between the following pairs of plots: 1 vs. 2, 1 vs. 3, 2 vs. 3, and 5 vs. 6 . All other paired comparisons were significant $(\mathrm{p}<0.05$; Table A2 in Appendix 1).

The 2-dimensional NMDS plot overlaid with sample plot information showed less clear groupings than the 3-dimensional NMDS plot and the CAP analysis; thus, the NMDS plot overlay is not included

Table 1. Results of the BACI-style analysis indicating main effects (dredged [D] vs. not dredged [ND], sample date, plot, and pre- vs. post-dredging) and interactions of main effects. Significant differences $(p<0.05)$ are in bold

\begin{tabular}{|c|c|c|c|c|c|c|c|c|}
\hline Factor (df) & $\begin{array}{c}\text { Overall } \\
\text { community }\end{array}$ & $\begin{array}{l}\text { No. of } \\
\text { species }\end{array}$ & $\begin{array}{c}\text { No. of } \\
\text { individuals }\end{array}$ & $\begin{array}{c}\text { Margalef } \\
\text { richness }\end{array}$ & $\begin{array}{c}\text { Pielou } \\
\text { evenness }\end{array}$ & $\begin{array}{l}\text { Shannon } \\
\text { diversity }\end{array}$ & $\begin{array}{c}\text { All } \\
\text { mollusks }\end{array}$ & $\begin{array}{c}\text { All } \\
\text { annelids }\end{array}$ \\
\hline \multicolumn{9}{|c|}{ D vs. ND (1) } \\
\hline $\mathrm{p}$ & 0.7965 & 0.2763 & 0.6982 & 0.2978 & 0.6075 & 0.535 & 0.6495 & 0.6014 \\
\hline MS & 2258.3 & 12.974 & 0.051158 & 10.857 & 0.059833 & 0.57847 & 264.4 & 2925.8 \\
\hline$F$ & 0.5638 & 12.988 & 0.16759 & 12.574 & 0.2888 & 0.39757 & 0.55591 & 0.67925 \\
\hline \multicolumn{9}{|c|}{ Sample date (11) } \\
\hline $\mathrm{p}$ & 0.0001 & 0.0001 & 0.0001 & 0.0001 & 0.0547 & 0.0128 & 0.0001 & 0.0001 \\
\hline MS & 3438 & 57.258 & 0.47312 & 19.223 & 0.043824 & 0.43148 & 2743 & 3079.6 \\
\hline$F$ & 40.487 & 12.8 & 56.501 & 5.749 & 19.832 & 26.668 & 26.458 & 3.752 \\
\hline \multicolumn{9}{|l|}{ Plot (4) } \\
\hline $\mathrm{p}$ & 0.0001 & 0.1763 & 0.0002 & 0.0423 & 0.0001 & 0.0001 & 0.018 & 0.0001 \\
\hline MS & 4902 & 75.237 & 0.71304 & 0.91381 & 0.28102 & 18.362 & 1699.1 & 4553.9 \\
\hline$F$ & 57.727 & 16.819 & 85.153 & 27.329 & 12.717 & 11.349 & 16.389 & 55.481 \\
\hline \multicolumn{9}{|c|}{ Pre- vs. post-dredging (1) } \\
\hline $\mathrm{p}$ & 0.09 & 0.0076 & 0.2873 & 0.0064 & 0.1956 & 0.2556 & 0.0841 & 0.0805 \\
\hline MS & 13057 & 1204.1 & 0.8547 & 69.162 & 0.14217 & 13.029 & 14615 & 13893 \\
\hline$F$ & 33.129 & 21.217 & 14.634 & 24.903 & 23.259 & 17.465 & 41.306 & 39.308 \\
\hline \multicolumn{9}{|c|}{ Pre- vs. post- $\times$ D vs. ND (1) } \\
\hline $\mathrm{p}$ & 0.3748 & 0.8678 & 0.9377 & 0.9784 & 0.6314 & 0.8825 & 0.4947 & 0.2255 \\
\hline MS & 1007.6 & 0.06547 & 0.013214 & 0.021612 & 0.004714 & 0.058697 & 612.81 & 1704.9 \\
\hline$F$ & 10.666 & 0.41412 & 0.33171 & 0.25585 & 0.66917 & 0.40667 & 0.89015 & 12.773 \\
\hline \multicolumn{9}{|c|}{ Pre- vs. Post- $\times$ plot $(4)$} \\
\hline $\mathrm{p}$ & 0.2032 & 0.479 & 0.0627 & 0.0232 & 0.2634 & 0.044 & 0.1258 & 0.3472 \\
\hline MS & 1026 & 39.852 & 0.20529 & 10.568 & 0.030294 & 0.44907 & 1275.6 & 903.87 \\
\hline$F$ & 12.082 & 0.89087 & 24.516 & 31.606 & 13.709 & 27.755 & 12.303 & 11.012 \\
\hline \multicolumn{9}{|c|}{ Sample date × D vs. ND (11) } \\
\hline $\mathrm{p}$ & 0.8402 & 0.2095 & 0.5911 & 0.693 & 0.9632 & 0.9159 & 0.9935 & 0.0677 \\
\hline MS & 720.78 & 63.169 & 0.071688 & 0.24608 & 0.007831 & 0.072278 & 538.07 & 1120.7 \\
\hline$F$ & 0.84882 & 14.121 & 0.85611 & 0.73597 & 0.35438 & 0.44673 & 0.519 & 13.654 \\
\hline
\end{tabular}



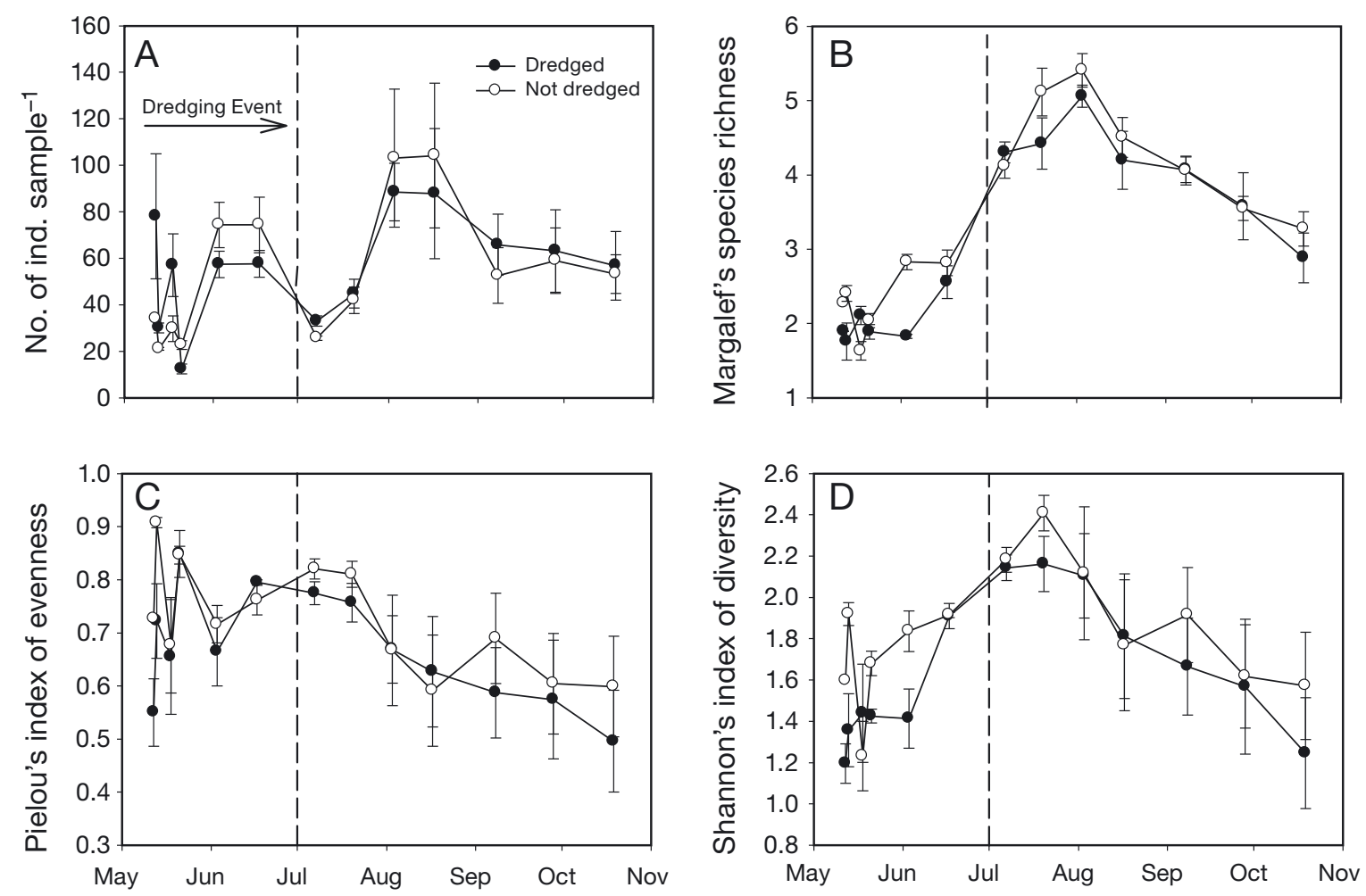

Fig. 2. Graphs of ecological indices: (A) number of individuals, per Smith-McIntyre sample, (B) Margalef's species richness, (C) Pielou's index of evenness, and (D) Shannon's index of diversity for the benthic assemblages comparing mean values and standard error for dredged (Plots 1, 3, 5) plots and not dredged controls (Plots 2, 4, 6) over time in 2009

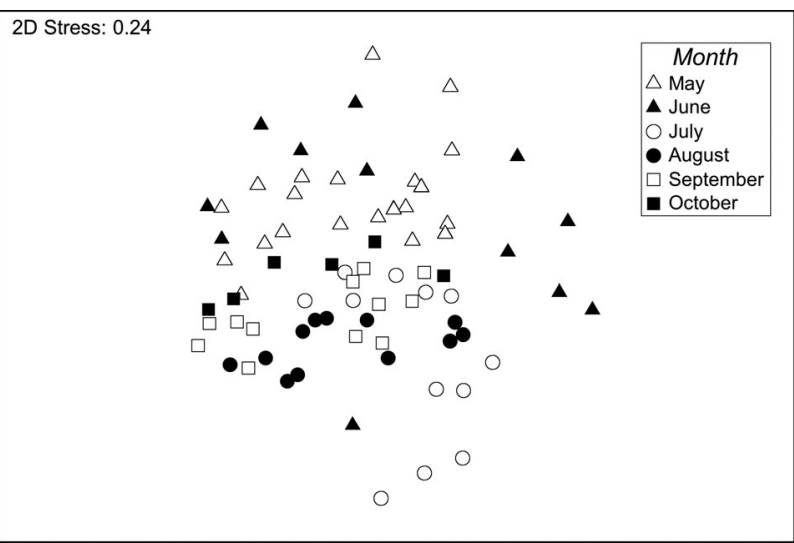

Fig. 3. Multidimensional scaling plots of benthic assemblages overlaid with sampling month in 2009. Data have been square-root transformed. Resemblance: Bray-Curtis similarity

here. However, samples grouped by plot in an ANOSIM test yielded significant differences that were similar to the grain size results (global R statistic $=0.214, p=0.01$ ). Significant differences in species assemblages were observed for every pair of plots compared, except Plots 1 vs. 2; 1 vs. 3; 2 vs. 3; 4 vs. 5, and 5 vs. 6 (Table A3 in Appendix 1). All other pairwise comparisons yielded a $\mathrm{p}<0.05$. These results matched those of the grain size analysis (Table A2), with the exception of Plot 4 vs. 5, which had a significant difference in grain size but insignificant difference in community composition. The first axis of the CAP model helped identify the subset of species that correlated with grain size differences (Table A4 in Appendix 1). The size of this canonical correlation was reasonably large $(\delta=0.91)$. The amphipods $A m$ pelisca spp. and Calliopius laeviusculus, the polychaetes Glycera spp., and the crustaceans Pagurus longicarpus and Crangon septemspinosa were abundant in fine sand (Plots 1, 2, and 3). The bivalves Mercenaria mercenaria and Yoldia limatula, the polychaetes Clymenella torquata and Nephtys spp., the amphipod Leptocheirus pinguis, and the crustaceans Pinnixa spp. were highly associated with very fine sand (Plots 5 and 6). Consistent significant differences were observed between communities for nearly all pairs of plots (Table A3). However, pairwise comparisons of plots with similar grain sizes (i.e. 1 vs. 2 and 5 vs. 6) yielded non-significant p-values. We used repeated-measures tests to compare post-dredging samples between Plots 1 and 2 (fine sand) and between Plots 5 and 6 (very fine sand) for the following parameters: total annelid abundance, total mollusk 
abundance (primarily $<10 \mathrm{~mm}$ in length), number of species, number of individuals, Margalef richness, Pielou evenness, and Shannon diversity. Repeated-measures tests were significant only for number of species between Plots 1 and 2 (fine sand; $p=0.041$ ) and in mollusk abundance between Plots 5 and 6 (very fine sand; $p=0.022$ ). Strong similarities among plots with similar sediment characteristics independent of dredging activity (i.e. 1 and 2 vs. 5 and 6 ) were evident especially when repeated measures for number of individuals and Shannon diversity were plotted (Fig. 4). Community differences due to sediment type were most apparent from July through the end of the experiment.

\section{Finfish and macrofaunal abundance}

ANOSIM indicated that the composition of juvenile fish communities did not differ significantly $(\mathrm{p}=0.687)$ between dredged and not dredged plots, and no association with sediment grain size was found. Black sea bass Centropristis striata and winter flounder Pseudopleuronectes americanus were the most abundant fish species observed (Table 2). Macrofaunal species collected most commonly by beam trawl included the spider crab Libinia spp., black fingered mud crab Xanthidae spp., longfin squid Loligo pealeii, and sea star Asterias forbesi. The relatively low density of invertebrates sampled throughout the experiment did not allow for statistical analysis across treatments.
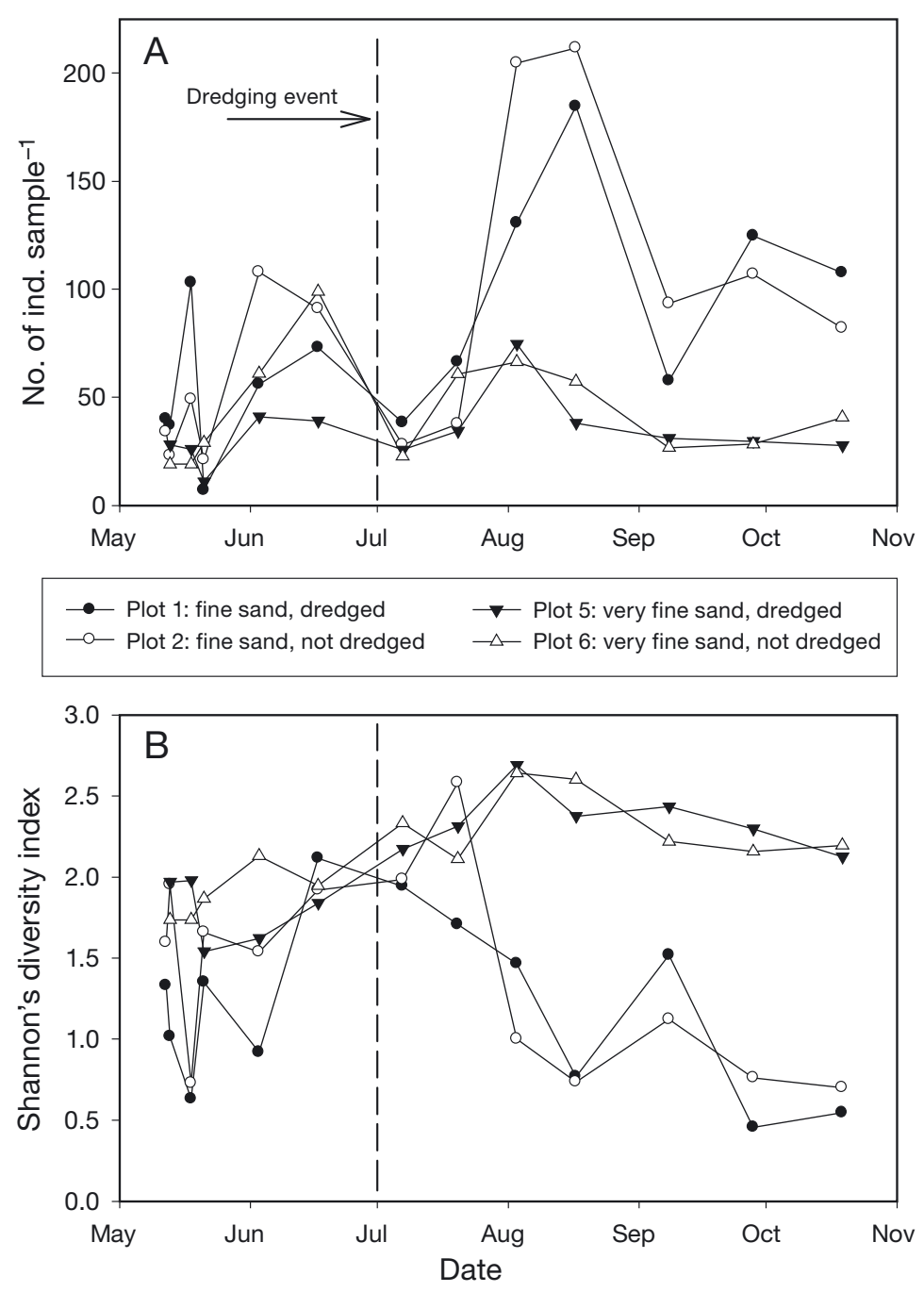

Fig. 4. (A) Number of individuals per Smith-McIntyre sample and (B) Shannon diversity indices for paired dredged and not dredged plots in 2009 with similar sediment characteristics (i.e. 1 and 2 [fine sand] vs. 5 and 6 [very fine sand])
Table 2. Number of juvenile fish species collected by beam trawl in all plots $(\mathrm{n}=54$ tows $)$

\begin{tabular}{|c|c|c|}
\hline Common name & Scientific name & $\begin{array}{l}\text { Total } \\
\text { caught }\end{array}$ \\
\hline Black sea bass & Centropristis striata & 26 \\
\hline Winter flounder & $\begin{array}{l}\text { Pseudopleuronectes } \\
\text { americanus }\end{array}$ & 14 \\
\hline Striped searobin & Prionotus evolans & 8 \\
\hline Summer flounder & Paralichthys dentatus & 6 \\
\hline Northern pipefish & Syngnathus fuscus & 5 \\
\hline Northern searobin & Prionotus carolinus & 3 \\
\hline Windowpane flounder & Scophthalmus aquosus & 3 \\
\hline Smallmouth flounder & Etropus microstomus & 2 \\
\hline Bay anchovy & Anchoa mitchilli & 1 \\
\hline Fourbeard rockling & Enchelyopus cimbrius & 1 \\
\hline Pollock & Pollachius virens & 1 \\
\hline
\end{tabular}

\section{DISCUSSION}

Although benthic community structure and ecological indices among experimental plots were affected significantly by season and sediment type, we found no effects from hydraulic dredging. Benthic faunal assemblages associated with clam beds in shallow waters are well adapted to frequent natural disturbance common in the coastal zone. The effects of hydraulic dredging may be relatively minor for benthic organisms that have adapted to the physical stresses of dynamic environments (Bigford 1997, DeAlteris et al. 1999, Constantino et al. 2009). Disruption from episodic storm events, tides, and currents may predispose these areas to habitation by tolerant and resilient species with short life spans, high 
reproductive rates, and life-history characteristics which allow them to avoid, survive, or quickly recover from a brief dredging event. In Portugal, Constantino et al. (2009) found that harvesting with a dragged, toothed, dry dredge impacted seafloor sediments much like the action of storm events and surface waves. Seasonal storm events, temperature discrepancies, and water turbulence can exert shortterm influences on the population structure of the benthos (Alves et al. 2003). Local environmental conditions and macrobenthic community composition may act to mediate effects of discrete hydraulic dredge harvesting (Wijnhoven et al. 2011). Further, variability in recruitment, predation, species interactions, and abiotic variations among benthic communities may result in spatial patchiness which exceeds or masks the anthropogenic effects of hydraulic harvesting (Sparsis et al. 1993). The dynamic nature of the inshore environment and the resilience of associated benthic communities may account for the absence of an observed dredging impact during our study.

Dredging was conducted during mid-summer for about $1 \mathrm{~h}$ in each experimental plot, resulting in the harvest of a substantial number of marketable clams. This intensity of dredging disturbance is typical of commercial hard clam cultivation on leased grounds in Connecticut. Once harvested, a bed may not be dredged again for 3 to $5 \mathrm{yr}$, allowing time for 'seed' clams to grow to market size. This activity contrasts with offshore surfclam Spisula solidissima, ocean quahog Arctica islandica, and sea scallop Placopecten magellanicus fisheries, where the spatial and temporal scales of continual fishing effort are greater, resulting in a greater potential for impact (Mercaldo-Allen \& Goldberg 2011). A meta-analysis of 56 previous experimental studies on dredging showed that gear type, region, and taxonomic class had the greatest influence on the benthic biota (Collie et al. 2000). Several previous studies on inshore clam dredging using a Maryland soft-shell escalator, hydraulic clam dredge (Godcharles 1971), hydraulic bullrake (Sparsis et al. 1993), mechanical hydraulic shellfish harvester (Maier et al. 1998), and hydraulic dredge (Wijnhoven et al. 2011) documented little to no impact of harvesting. The short-term duration of dredge harvesting and the limited size of the area being cultivated during our study may contribute to the lack of measurable effects on the benthic community we observed.

Most studies of hydraulic dredging report some level of immediate damage or mortality to organisms located in the direct path of the harvesting device, but the extent and duration of effects are generally limited (e.g. Coen 1995). In a study of hydraulic escalator dredging in Maryland, an initial disruption of the epibenthic community was observed, but this did not significantly reduce benthic infaunal populations (Drobeck \& Johnston 1982). Our first post-dredge sample was collected within $3 \mathrm{~d}$ of hydraulic dredging and indicated no significant difference between dredged and not dredged treatments. The SmithMacIntyre grab was not efficient at sampling larger, marketable hard clams that occur at relatively low spatial densities, thus precluding a comparison of direct effects on the target species. Based on our results, any immediate impacts of dredging on species abundance and diversity were resolved quickly. Benthic organisms, generally resilient to disturbance, did not appear to have suffered measurable mortality as a direct result of dredging in our study.

The low numbers of finfish and macroinvertebrates collected during the beam trawl sampling likely resulted from short tow distances on the relatively small experimental plots. Only 2 to $3 \mathrm{~min}$ were required for the beam trawl to cover the length of each 0.67 ha plot, and trawling was limited to 2 replicate passes to avoid adding additional impact to the seafloor. Since clam beds generally have low-relief bottom with structure limited to cobble and broken shell, abundance of juvenile fish and invertebrates may have been lower than at areas of more complex habitat further inshore. Although densities were low, the suite of species collected in the beam trawls indicated that working clam beds, both recently dredged and not dredged, provide habitat for a variety of mobile fauna.

The BACI design we used enabled us to observe the benthic community prior to the dredging disturbance and, subsequently, to follow seasonal changes in species composition. Pairwise comparisons of benthic assemblages between dredged and not dredged plots remained similar, while values varied seasonally by sample date. Significant differences were found between all paired months except for May and October, suggesting that early and late season communities may have a similar composition due to reduced biological activity during those periods. In several other studies, seasonal changes in benthic community structure were greater than observed effects of shellfish cultivation. In a 2 yr study, Alves et al. (2003) used a dragged, toothed, clam dredge to harvest clams in spring/summer and fall. Although significant shortterm changes in meio- and macrobenthic communities were observed, natural changes associated with season had a greater impact on ecological parameters. Godcharles (1971) observed faunal variations 
in Florida to be seasonal in nature, rather than a result of harvesting with a Maryland escalator clam dredge. In a study of hard clam cultivation in Narragansett Bay, Rhode Island, USA, Sparsis et al. (1993) found seasonal changes and natural variability to be greater than the effects of one-time harvesting by hydraulic bullrake. Results from these studies and from our experiment suggest that seasonal changes in benthic communities may be more apparent than effects from discrete dredge harvest events.

We found strong associations with grain size classifications and the abundance of individual species. Amphipods were generally associated with fine sandy sediments, while bivalves were associated with very fine sand. The opportunistic, deposit-feeding polychaete Pectinaria gouldii (Whitlatch 1974) was most associated with fine sand sediment, as similarly reported by Sanders (1956) in a description of benthic organisms in Long Island Sound. Relationships among sediment grain size and faunal density and/or number of taxa have been well described (e.g. Gray 1974, Snelgrove \& Butman 1994, Mancinelli et al. 1998) and are similar to results we observed. Differences in benthic community composition related to regional environments and local sediment type are typical within Long Island Sound (Zajac et al. 2000).

Evaluation of dredging effects on the benthic community is highly specific to local habitat, environment, and level of physical impact. Studies designed to answer the question 'does shellfish dredging impact benthic communities?' are confounded by the variability associated with the marine environment. Unique attributes of a given clam bed, the season in which dredging is conducted, timing of recruitment, and the duration, intensity, and frequency of dredging all make it difficult to draw a single comprehensive conclusion with regard to dredging impacts. Our study addresses the effects of one-time harvesting on a specific study site in Long Island Sound. Future studies to further investigate dredging effects could include investigation of seasonality, assessment of biomass changes, analysis of functional feeding roles, and detection of possible cumulative effects.

We found that season and sediment grain size had greater effect on benthic community structure and ecological indices than a single hydraulic dredging event on a small spatial scale during our experiment on leased clam beds in Long Island Sound. Our experimental results indicate that hydraulic dredging did not significantly impact benthic communities. Ecological effects and recovery of the benthos after limited dredging may be similar to that which occurs after natural disturbance. We conclude that hydraulic shellfish dredging had minor effects and that cultivated shellfish beds support a wide diversity of organisms.

Acknowledgements. We thank Captains R. Alix and W. Schreiner for vessel operations, S. Auscavitch, S. DeCarli, M. Dixon, J. Esposito, J. Goggins, K. Harper, T. L. Nguyen, D. Redman, J. Reidy, G. Sennefelder, and A. Wu for technical support, and L. Williams of the Jesse D. Shellfish Company for dredging our study site and allowing us to sample his leased clam beds. The State of Connecticut, Dept of Agriculture, Bureau of Aquaculture's D. Carey and T. Barrell helped to coordinate experimental dredging and mark shellfish beds. This study was supported in part by the East Coast Shellfish Research Institute.

\section{LITERATURE CITED}

Alves FL, Chícharo L, Nogueira A, Regala J (2003) Changes in benthic community structure due to clam dredging on the Algarve coast and the importance of seasonal analysis. J Mar Biol Assoc UK 83:719-729

Anderson MJ, Gorley RN, Clarke KR (2008) PERMANOVA+ for PRIMER: guide to software and statistical methods. PRIMER-E, Plymouth

Baulch H (1999) Clear-cutting the ocean floor. Altern J 25:7

Bigford TE (1997) Environmental challenges facing the shellfish industry. In: MacKenzie CL Jr, Burrell VG, Rosenfield A, Hobart WL (eds) The history, present condition, and future of the molluscan fisheries of North and Central America and Europe, Vol 2. Pacific Coast and supplemental topics. NOAA Tech Rep NMFS 128:157-163

Clarke KR, Gorley RN (2006) PRIMER v6: user manual/ tutorial. PRIMER-E, Plymouth

Clarke KR, Warwick M (2001) Change in marine communities: an approach to statistical analysis and interpretation, 2nd edn. Plymouth Marine Laboratory, Plymouth

Coen LD (1995) A review of the potential impacts of mechanical harvesting on subtidal and intertidal shellfish resources. South Carolina Department of Natural Resources-Marine Resources Research Institute, Columbia, SC

Collie JS, Hall SJ, Kaiser MJ, Poiner IR (2000) A quantitative analysis of fishing impacts on shelf-sea benthos. J Anim Ecol 69:785-798

Connecticut Department of Agriculture (2011) Connecticut shell fishing industry profile. Available at: www.ct.gov/ $\mathrm{doag} / \mathrm{cwp} /$ view.asp?a=1369\&q=316994 (accessed 10 December 2011)

Constantino R, Gaspar MB, Tata-Regala J, Carvalho S and others (2009) Clam dredging effects and subsequent recovery of benthic communities at different depth ranges. Mar Environ Res 67:89-99

Dame D, Bushek D, Allen D, Edwards D and others (2000) The experimental analysis of tidal creeks dominated by oyster reefs: the pre-manipulation year. J Shellfish Res 19:361-369

> Dame R, Bushek D, Allen D, Lewitus A, Edwards D, Koepfler E, Gregory L (2002) Ecosystem response to bivalve density reduction: management implications. Aquat Ecol 36: 51-65

DeAlteris J, Skrobe L, Lipsky C (1999) The significance of seabed disturbance by mobile fishing gear relative to 
natural processes: a case study in Narragansett Bay, Rhode Island. Am Fish Soc Symp 22:224-237

Drobeck KG, Johnston ML (1982) Environmental impact of hydraulic escalator dredging on oyster communities. UMCEES Report 82-5 CBL, University of Maryland, Chesapeake Biological Laboratory, Solomons, MD

Ferreira JG, Hawkins AJS, Bricker SB (2007) Management of productivity, environmental effects and profitability of shellfish aquaculture-the Farm Aquaculture Resource Management (FARM) model. Aquaculture 264: 160-174

Gilkinson KD, Gordon DC Jr, MacIsaac KG, McKeown DL, Kenchington ELR, Bourbonnais C, Vass WP (2005) Immediate impacts and recovery trajectories of macrofaunal communities following hydraulic clam dredging on Banquereau, eastern Canada. ICES J Mar Sci 62:925-947

Godcharles MF (1971) A study of the effects of a commercial hydraulic clam dredge on benthic communities in estuarine areas. Department of Natural Resources, Marine Research Laboratory, Technical Series no. 64, St. Petersburg, FL, p 1-51

Gosner KL (1978) Peterson field guide Atlantic seashore. Houghton Mifflin Company, New York, NY

Gray JS (1974) Animal-sediment relationships. Oceanogr Mar Biol Annu Rev 12:223-261

Hewitt JE, Thrush SE, Cummings VJ (2001) Assessing environmental impacts: effects of spatial temporal variability at likely impact scales. Ecol Appl 11:1502-1516

Jolley JW (1972) Exploratory fishing for the sunray Venus clam Macrocallista nimbosa in northwest Florida. Department of Natural Resources, Marine Research Laboratory, Technical Series no. 67, St. Petersburg, FL, p 1-42

Kaiser MJ (2005) Thinking about experimental design. In: Kaiser MJ, Attrill MJ, Jennings S, Thomas DN and others (eds) Marine ecology: processes, systems, and impacts. Oxford University Press, New York, NY, p 464-474

Levy S (1998) Watery wastelands. New Sci 2134:40-44

> Lindahl O, Hart R, Hernroth B, Kollberg S and others (2005) Improving marine water quality by mussel farming a profitable solution for Swedish society. Ambio 34: 129-136

Long Island Sound Study (2011) Hard clam harvest. Available at: http://longislandsoundstudy.net/2010/06/hardclam-harvest/ (accessed 10 December 2011)

MacKenzie CL Jr, Morrison A, Taylor DL, Burrell VG Jr, Arnold WS, Wakida-Kusunoki AT (2002) Quahogs in eastern North America, Part I. Biology, ecology, and historical uses. Mar Fish Rev 64:1-55

Maier PP, Wendt PH, Roumillat WA, Steele GH, Levisen MV, Van Dolah R (1998) Effects of subtidal mechanical clam harvesting on tidal creeks. South Carolina Department of Natural Resources-Marine Resources Research Institute, Columbia, SC

Mancinelli G, Fazi S, Rossi L (1998) Sediment structural properties mediating dominant feeding types patterns in soft-bottom macrobenthos of the northern Adriatic Sea. Hydrobiologia 367:211-222

Mercaldo-Allen R, Goldberg R (2011) Review of the ecological effects of dredging in the cultivation and harvest of molluscan shellfish. NOAA Tech Memo NMFS-NE 220

> Morello EB, Froglia C, Atkinson RJA, Moore PG (2005) Impacts of hydraulic dredging on a macobenthic community of the Adriatic Sea, Italy. Can J Fish Aquat Sci 62: 2076-2087

Newell RIE (2004) Ecosystem influences of natural and cultivated populations of suspension-feeding bivalve molluscs: a review. J Shellfish Res 23:51-61

Pollock LW (1943) A practical guide to the marine animals of northeastern North America. Rutgers University Press, New Brunswick, NJ

Sanders HL (1956) Oceanography of Long Island Sound. X. The biology of marine bottom communities. Bull Bingham Oceanogr Collect 15:245-258

Shumway SE (2011) Preface. In: Shumway SE (ed) Shellfish aquaculture and the environment. John Wiley \& Sons, New York, NY, p 15-17

Smith RI (1964) Keys to marine invertebrates of the Woods Hole region. Marine Biological Laboratory, Woods Hole, MA

Snelgrove PVR, Butman CA (1994) Animal-sediment relationships revisited: cause versus effect. Oceanogr Mar Biol Annu Rev 32:111-177

Sparsis M, DeAlteris JT, Rice MA (1993) Effects of bottom cultivation on quahogs and other bottom invertebrates in Narragansett Bay. In: Rice MA, Grossman-Garber D (eds) Proc 2nd Rhode Island shellfish industry conference, Narragansett, Rhode Island, August 4, p 63-78

Stokesbury DE, Baker EP, Harris BP, Rheault RB (2011) Environmental impacts related to mechanical harvest of cultured shellfish, Chapter 11. In: Shumway SE (ed) Shellfish aquaculture and the environment. John Wiley \& Sons, New York, NY, p 319-338

Watling L (2005) The global destruction of bottom habitats by mobile fishing gears. In: Norse EA, Crowder LB (eds) Marine conservation biology. Island Press, Washington, DC, p 198-210

Watling L, Norse EA (1998) Disturbance of the seabed by mobile fishing gear: a comparison to forest clearcutting. Conserv Biol 12:1180-1197

Weiss HM (1995) Marine animals of southern New England and New York. State Geological and Natural History Survey of Connecticut, Hartford, CT

Whitlatch RB (1974) Food-resource partitioning in the deposit feeding polychaete Pectinaria gouldii. Biol Bull 147:227-235

Wijnhoven S, Escaravage V, Herman PMJ, Smaal AC, Hummel H (2011) Short and mid-long term effects of cockledredging on non-target macrobenthic species: a beforeafter-control-impact experiment on a tidal mudflat in the Oosterschelde (The Netherlands). PSZN I: Mar Ecol 32(Suppl 1):117-129

Wilcox RR (2003) Applying contemporary statistical techniques. Academic Press, New York, NY

Zajac RN, Lewis RS, Poppe LJ, Twichell DC, Vozarik J, DiGiacomo-Cohen ML (2000) Relationships between sea-floor structure and benthic communities in Long Island Sound at regional and benthoscape scales. J Coast Res 16:627-640 


\section{APPENDIX 1.}

Table A1. List of benthic invertebrate species sampled on dredged and not dredged clam beds

\begin{tabular}{|c|c|}
\hline Annelids & Ovalipes ocellatus \\
\hline Ampharete arctica & Pagurus longicarpus \\
\hline Amphitrite spp. & Pinnixa spp. \\
\hline Arabella iricolor & Pleustidae \\
\hline Capitella capitata & Polyonyx spp. \\
\hline Clymenella torquata & Unciola irrorata \\
\hline Diopatra cuprea & Upogebia affinis \\
\hline $\begin{array}{l}\text { Drilonereis spp. } \\
\text { Eumida sanguinea }\end{array}$ & Xanthidae \\
\hline Eupleura caudata & Echinoderms \\
\hline Glycera spp. & Asterias forbesi \\
\hline Goniadidae & Leptosynapta spp. \\
\hline Leitoscoloplos fragilis & \\
\hline Lepidonotus spp. & Mollusks \\
\hline Lumbrineris spp. & Aceteocina canaliculata \\
\hline Melinna cristata & Anadara transversa \\
\hline Nephtys spp. & Busycon carica \\
\hline Nereis spp. & Busycotypus \\
\hline Nicomache lumbricalis & canaliculatus \\
\hline Oligochaeta & Crassostrea virginica \\
\hline Ophelia spp. & Crepidula fornicata \\
\hline Orbiniidae & Ensis directus \\
\hline Pectinaria gouldii & Epitonium spp. \\
\hline Pherusa spp. & Euspira heros \\
\hline Polydora spp. & Haminoea solitaria \\
\hline Sabellaria vulgaris & Ilyanassa trivittata \\
\hline $\begin{array}{l}\text { Spiochaetopterus } \\
\text { oculatus }\end{array}$ & Mercenaria mercenaria \\
\hline Spionidae & Mulinia lateralis \\
\hline Syllidae & Mya arenaria \\
\hline & Pandora gouldiana \\
\hline Arthropods & Petricola pholadiformis \\
\hline Ampelisca spp. & Terebra dislocata \\
\hline Callinectes sapidus & Turbonilla spp. \\
\hline Calliopius laeviusculus & Urosalpinx cinerea \\
\hline Crangon septemspinosa & Yoldia limatula \\
\hline Leptocheirus pinguis & \\
\hline Libinia spp. & Nemerteans \\
\hline Listriella spp. & Cerebratulus lacteus \\
\hline Mysidacea & Tetrastemma spp. \\
\hline
\end{tabular}

Table A2. Comparison of grain size differences between study plots. Significant differences $(p<0.05)$ are in bold

\begin{tabular}{|c|c|}
\hline Plot comparison & $\mathrm{p}$-value \\
\hline 1 vs. 2 & 0.3500 \\
\hline 1 vs. 3 & 0.0876 \\
\hline 1 vs. 4 & $<0.001$ \\
\hline 1 vs. 5 & $<0.001$ \\
\hline 1 vs. 6 & $<0.001$ \\
\hline 2 vs. 3 & 0.2918 \\
\hline 2 vs. 4 & $<0.001$ \\
\hline 2 vs. 5 & $<0.001$ \\
\hline 2 vs. 6 & $<0.001$ \\
\hline 3 vs. 4 & $<0.001$ \\
\hline 3 vs. 5 & $<0.001$ \\
\hline 3 vs. 6 & $<0.001$ \\
\hline 4 vs. 5 & 0.0076 \\
\hline 4 vs. 6 & $<0.001$ \\
\hline 5 vs. 6 & 0.3820 \\
\hline
\end{tabular}

Table A3. ANOSIM comparing benthic species assemblages between individual plots. Significant differences $(p<0.05)$ are in bold

\begin{tabular}{|lrr|}
\hline Plot comparison & R-statistic & p-value \\
\hline 1 vs. 2 & -0.039 & 0.858 \\
1 vs. 3 & 0.053 & 0.135 \\
$\mathbf{1}$ vs. $\mathbf{4}$ & 0.338 & $\mathbf{0 . 0 0 1}$ \\
$\mathbf{1}$ vs. $\mathbf{5}$ & 0.455 & $\mathbf{0 . 0 0 1}$ \\
$\mathbf{1}$ vs. $\mathbf{6}$ & 0.590 & $\mathbf{0 . 0 0 1}$ \\
2 vs. 3 & -0.003 & 0.476 \\
$\mathbf{2}$ vs. $\mathbf{4}$ & 0.198 & $\mathbf{0 . 0 0 5}$ \\
$\mathbf{2}$ vs. $\mathbf{5}$ & 0.264 & $\mathbf{0 . 0 0 1}$ \\
$\mathbf{2}$ vs. $\mathbf{6}$ & 0.427 & $\mathbf{0 . 0 0 1}$ \\
$\mathbf{3}$ vs. $\mathbf{4}$ & 0.110 & $\mathbf{0 . 0 2 8}$ \\
$\mathbf{3}$ vs. $\mathbf{5}$ & 0.202 & $\mathbf{0 . 0 0 4}$ \\
$\mathbf{3}$ vs. $\mathbf{6}$ & 0.404 & $\mathbf{0 . 0 0 1}$ \\
$\mathbf{4}$ vs. 5 & 0.022 & 0.299 \\
$\mathbf{4}$ vs. $\mathbf{6}$ & 0.164 & $\mathbf{0 . 0 0 6}$ \\
5 vs. 6 & 0.016 & 0.325 \\
\hline
\end{tabular}

Table A4. Dominant species associated with paired plots as determined by canonical analysis of principal coordinates (Spearman correlations $>25 \%$ ). Plots 1 to 3 were nominally classified as having fine sand (FS) (mean $[ \pm \mathrm{SE}] \Phi=2.50 \pm$ $0.03)$. Plots 5 and 6 were nominally classified as having very fine sand (VFS) (mean $[ \pm \mathrm{SE}] \Phi=3.15 \pm 0.06$ )

\begin{tabular}{|ll|}
\hline Plots 1, 2, 3, FS & Plots 5, 6, VFS \\
\hline Ampelisca spp. & Clymenella torquata \\
Glycera spp. & Nephtys spp. \\
Pagurus longicarpus & Yoldia limatula \\
Crangon septemspinosa & Mercenaria mercenaria \\
Calliopius laeviusculus & Pinnixa spp. \\
& Leptocheirus pinguis \\
\hline
\end{tabular}

